\title{
The taxonomic utility of micromorphological characters in Australian and New Zealand Elymus species (Poaceae)
}

\author{
S. Wang and M.J. Henwood
}

\begin{abstract}
Wang, S. and Henwood M.J. (School of Biological Sciences, Macleay Building A12, The University of Sydney, NSW 2006, Australia) 1999. The taxonomic utility of micromorphological characters in Australian and New Zealand Elymus species (Poaceae). Telopea 8(3): 351-362. A Scanning Electron Microscopy (SEM) survey of rachillas, calluses and paleae of Australian and New Zealand species of Elymus revealed a number of taxonomically informative micromorphological characters. Such characters included: the indumentum on the rachillas, the shape of the rachilla apices, the shape and indumentum of calluses, and the extent to which palea tips extended beyond the flanks. The micromorphological characters confirmed the limits of some taxa and, in the case of E. scaber (R. Br.) À. Löve, indicated some novel groupings within this taxonomically difficult species complex. The characters were relatively well correlated with traditional, but often poorly defined, numerical characters as they are applied to the E. scaber complex. Furthermore, the micromorphological characters co-varied somewhat with the different breeding systems that characterise the E. scaber complex. The novel characters documented in this study have the advantage over traditional numerical characters in that they are more rigorously definable and, as a consequence, taxonomically more informative.
\end{abstract}

\section{Introduction}

Delimitation of the Australian species of Elymus has been a matter of debate for over 100 years. Nine species of Elymus are currently recognised as occurring in Australia and/or New Zealand. Within New Zealand, E. apricus À. Löve \& Connor, E. enysii (Kirk) À. Löve \& Connor, E. falcis Connor, E. sacandros Connor, E. solandri (Steud.) Connor and E. tenuis (Buchanan) À. Löve \& Connor are considered to be endemic. One species containing two varieties, E. scaber (R. Br.) À. Löve var. scaber and E. scaber var. plurinervis (Vickery) B. Simon, is endemic to Australia. The geographic distribution of a further two species, E. rectisetus (Nees in Lehm.) À. Löve \& Connor and E. multiflorus (Hook. f.) À. Löve \& Connor is contentious. Connor (1994) considered each to be present in New Zealand and Australia, whereas Australian workers (notably Vickery 1951; Simon 1980; Wheeler, Jacobs \& Norton 1982; Jessop 1986) treated them as part of a broadly defined, but geographically restricted E. scaber (= Agropyron scabrum (R. Br.) P. Beauv.). Recently, E. multiflorus has been included in Australian state floras (Ross 1989; Jacobs \& Hastings 1993; Simon 1993; Walsh 1994). Elymus scaber is not currently considered to occur in New Zealand (Löve \& Connor 1982; Connor 1994). Thus, the delimitation of Australian taxa depends on the resolution of the taxonomic composition of E. scaber s.l. and whether or not any part of this taxon can be accommodated in the otherwise New Zealand species, E. rectisetus.

The recognition of taxa within Australia has, until recently, been hindered by a lack of information on the reproductive biology. Hair (1956), Connor (1954, 1956, 1962a, 1962b, 1994), and Löve and Connor (1982) have done much to document both the cytology and the reproductive biology of the austral species of Elymus. All Australian 
taxa are hexaploids $(2 n=6 x=42)$ as is the majority of New Zealand species, the exceptions being E. enysii $(2 n=4 x=28)$ and E. tenuis $(2 n=8 x=56)$ (Connor 1954). The ploidy level of $E$. sacandros has not as yet been documented.

The reproductive biology of the group has received some attention, although Australian workers have been somewhat reluctant to embrace the taxonomic potential of this source of data for their classifications. Connor (1994), Crane and Carmen (1987), Torabinejad et al. (1987) and Murphy and Jones (1999) have each documented a range of reproductive strategies in the austral taxa of this genus. It is apparent from this accumulated work that the Australian hexaploid taxa are a mix of both sexual and apomictic individuals. The New Zealand species are all sexual with the exception of the apomict E. rectisetus.

Most, if not all, of the variation in E. scaber s.l. can be seen in the typical variety. The sexual taxon, E. scaber var. plurinervis, on the other hand, is morphologically homogeneous and relatively well circumscribed. Traditionally, recognition of entities within E. scaber has depended on the emphasis placed upon a limited number of often subjectively defined morphological characters. Such characters have included the relative length of lemma awns and the dimensions of the glumes and number of their nerves (Vickery 1951; Simon 1993; Walsh 1994). In addition, the extent of lemma awn curvature and incision of their apices, the shape and degree of incision of palea apices, leaf-blade aestivation, the relative size of auricles and the length of anthers have been identified by Connor (1994) as being taxonomically relevant for delimitation of New Zealand species.

Attempts to reconcile all sources of variation have resulted in a surprising lack of taxonomic congruence. Crane and Carmen (1987) and Murphy and Jones (1999) placed sexual individuals with short awns in E. scaber, whereas Torabinejad et al. (1987) considered this form to be allied with New Zealand E. multiflorus. Connor agreed with the latter workers by placing short-awned individuals from Queensland in E. multiflorus.

Elymus rectisetus is currently described as apomictic with long-awns (Torabinejad et al. 1987; Carman \& Wang 1992; Connor 1994; Murphy \& Jones 1999). Apomictic individuals with long awns from lowland areas of Australia were regarded by Crane and Carmen (1987) as conforming to E. rectisetus. In contrast, they considered that montane individuals with highly fertile seeds and intermediate to long lemma awns constituted a separate group, but did not recognise the group taxonomically. Murphy (pers. comm.) has recently indicated that short-awned individuals of E. scaber var. scaber are not exclusively sexual. A multivariate analysis of the E. scaber complex and allied species (Wang \& Henwood, unpublished data) indicated that E. scaber var. scaber comprises a range of lemma awn lengths. This result is not in conflict with the holotype of E. scaber for it has short awns.

It is intriguing, then, that despite the increase of knowledge on the reproductive biology, and the cytological and morphological variation within Elymus, the taxonomic limits of E. scaber s.l. remain elusive. Thus, it is apparent that if the nature and number of taxonomic entities within the E. scaber complex is to be clarified, what is required is a suite of less equivocal and/or mutable morphological characters.

A similar situation to that outlined above can be seen in a number of groups from a range of taxonomic ranks within Elymus. In an attempt to provide a more robust classification, some workers have employed a combined genomic and morphological approach (Salomon \& Lu 1992; Lu 1995). In order to find more readily applicable morphological characters, these workers examined the micromorphology of paleae, calluses and lemmas. Salomon and Lu (1992) found that the palea apex shape and the size of palea cilia were good predictors of genome constitution. A subsequent study by 
$\mathrm{Lu}$ (1995) revealed considerable variation in the shape and indumentum of calluses, and in the indumentum of rachillas within the 'E. parviglumis group'.

Given the success of these workers with micromorphological characters, we undertook an SEM survey of micromorphological variation within the paleae, calluses and rachillas of Australian and New Zealand species of Elymus. Whilst our intention was primarily to derive characters that might be applicable to resolving the taxonomic structure within E. scaber s.l., we have taken a broad approach and have included all New Zealand species in our study.

\section{Material and methods}

A total of 54 specimens, representing all New Zealand and Australian taxa (either recognised formally or informally), were selected (Table 1). Special attention was given to selecting individuals representative of the morphological range encountered within the E. scaber complex. As with many such studies, the destructive nature of our sampling prevented us from using tissue from the holotypes. However, in all cases we endeavoured to use material from collections that matched the holotype as closely as possible.

Two to three florets (together with their rachillas) were taken from the mid-section of spikelets located in the lower half of each inflorescence. The component parts of each floret were mounted on aluminium stubs using double-sided carbon tape, and were coated with $20 \mathrm{~nm}$ of gold in an Edwards sputter coater. Secondary electron images of the specimens were viewed using a Phillips 505 SEM operating at $10 \mathrm{kV}$, and photographs were recorded on Ilford FP4 Plus 120 roll film.

\section{Results}

A summary of the results is presented in Table 2. Three broad groups of taxa could be delimited by a combination of callus, rachilla and palea micromorphological characters (see below). Rachillas were found to vary in the shape of the apices, the extent of their indumentum and the angle formed between the apex and axis of the rachilla. Similarly, calluses were observed to vary in a range of attributes including the shape and curvature of their abaxial surfaces, the extent of thickening along the adaxial margins and in the details of their indumentum. The extent to which the palea tips extended beyond the palea flanks was also found to be informative in a general way. However, palea characters such as the shape of the apices and the depth of incision were found to be more relevant in determining subgroups of taxa within one of the more broadly defined groups (see discussion below).

\section{Rachillas}

All individuals had rachillas with an indumentum (Table 2). However, the length and density of trichomes differed between taxa. The rachillas of E. enysii, E. scaber var. plurinervis and E. multiflorus were characterised by short trichomes (Fig. 1e, c, d respectively), whereas both short and long trichomes were observed on the rachillas of E. tenuis, E. falcis and E. solandri. In contrast, rachillas of E. rectisetus (of both New Zealand and putative Australian origin), E. scaber var. scaber, E. apricus (not shown) and E. sacandros regularly had long trichomes (Fig. 1a, b, f). 
Table 1. Specimens used for SEM investigation. New Zealand specimens are assigned to taxa according to Connor (1994), Australian specimens are assigned to taxa according to Wang and Henwood (in preparation). Herbarium abbreviations follow Holmgren et al. (1990).

\section{Australia}

Taxon

E. rectisetus

E. rectisetus

E. rectisetus

E. rectisetus

E. rectisetus

E. rectisetus

E. rectisetus

E. rectisetus

E. scaber var. scaber

E. scaber var. scaber

E. scaber var. scaber

E. scaber var. scaber

E. scaber var. scaber

E. scaber var. scaber

E. scaber var. scaber

E. scaber var. scaber

E. scaber var. scaber

E. scaber var. plurinervis

E. scaber var. plurinervis

E. scaber var. plurinervis

E. scaber var. plurinervis

E. multiflorus

E. multiflorus

E. multiflorus

E. multiflorus

E. multiflorus

E. multiflorus

E. multiflorus

E. multiflorus

E. multiflorus

\section{Collector}

R. Bates $15856 \mathrm{BRI}$

S. Wang 95103 SYD

N.C. Beadle s.n. SYD

B.J. Lepschi 2027 PERTH

A.D.J. Piesse $247 \mathrm{MEL}$

S. Wang 95087 SYD

S. Wang 95001 SYD

S. Wang 95041 SYD

S. Wang 95104 SYD

S. Wang 95135 SYD

J.H. Willis s.n. MEL 521279

J.S. Whinray $709 \mathrm{MEL}$

A. Brown $14 \mathrm{MEL}$

J.H. Hemsley s.n. HO 91358

S. Wang 95128 SYD

S. Wang 95136 SYD

J.H. Willis s.n. MEL 1560495

S. Wang 95153 SYD

S.L. Everist 811A MEL

R.J. Fensham 1728 BR

R.J. Fensham 1343 BRI

K.R. Thiele $249 \mathrm{MEL}$

S. Wang 9517 SYD

A. Beauglehole $32316 \mathrm{MEL}$

S. Wang 95140 SYD

S. Wang 95158 SYD

S. Wang 95132 SYD

A. Bell s.n. MEL 1560416

S. Wang 95100 SYD

S. Wang 95129 SYD

\section{New Zealand}

\section{Taxon Collector}

E. apricus

V. Zotov s.n. CHR 95426

E. apricus

P.N. Johnson 1220 CHR

E. apricus

V. Zotov s.n. CHR 19722

E. enysii

M.J.A. Lempson $3442 \mathrm{CHR}$

E. enysii

A.P. Druce 1345 CHR

E. enysii

E. falcis

A.E. Esler $3117 \mathrm{CHR}$

E. falcis

E. falcis

Melville $6021 \mathrm{CHR}$

H.E. Connor s.n. CHR 402714

E. multiflorus

H.H. Allan s.n. CHR 9514

E. multiflorus

D. Petrie s.n. CHR 1595

D. Petrie s.n. CHR 1594

E. multiflorus

P.J. de Lange $832 \mathrm{CHR}$

E. rectisetus

A.P. Druce s.n. CHR 387016

E. rectisetus

A.P. Druce s.n. CHR 209684

E. rectisetus

S. Aiken $2830 \mathrm{CHR}$

E. sacandros

A.P. Druce s.n. CHR 387017

E. sacandros

A.P. Druce s.n. CHR 279258

E. sacandros

A.P. Druce s.n. CHR 279243

E. solandri

H.E. Connor s.n. CHR260318

E. solandri

P. Wardle s.n. CHR 223898

E. solandri Molloy \& Campbell CHR 212078

E. tenuis

A.P. Druce s.n. CHR 402401

E. tenuis

R. Mason 10575. CHR

E. tenuis

A.P. Druce s.n. CHR 249122 
Table 2. Variation of rachillas, calluses and paleae within Australian and New Zealand Elymus species ( $\mathrm{A}=$ Australian material, $\mathbf{N}=\mathbf{N e w}$ Zealand material). Rachilla: angle between the margin of the apex (side view) and the axis of rachilla; apex shape: oblate (obl), elliptical (el), ovate (ov), obovate (ob), circular (c); indumentum long and covering callus base (Ic), long and not covering callus base (l); short (s). Callus: outline broadly triangular (b), triangular (t), narrowly triangular $(n)$; tip thickened $(+)$, not thickened $(-)$; dorsal surface rounded $(r)$, flat $(f)$, sunken $(s)$; dorsal surface glabrous (g), glabrescent (gs); trichomes restricted to margins $(\mathrm{m})$, trichomes distributed on surface (s); margin thickening extending approximately to the mid-point (I), restricted to below the mid-point $(s)$; ventral surface raised $(+)$, flat or sunken $(-)$. Palea apex: truncate or obtuse $(\cap)$, pointed $(\wedge)$; entire $(e)$, retuse $(r)$, bifid $(b)$; average length of tip beyond flanks.

\begin{tabular}{|c|c|c|c|c|c|c|c|c|c|c|c|c|}
\hline & & Rachilla & & & & $\mathrm{Ca}$ & & & & & alea a & pex \\
\hline & $\frac{b}{\frac{D}{D}}$ & 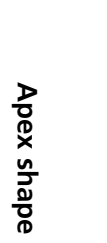 & 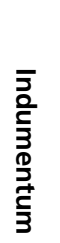 & 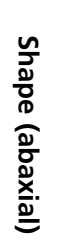 & 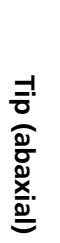 & 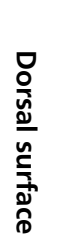 & 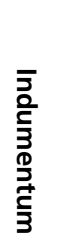 & 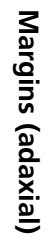 & 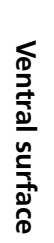 & $\begin{array}{l}\text { n } \\
\frac{a}{0} \\
\frac{0}{0}\end{array}$ & $\begin{array}{l}\bar{\Sigma} \\
\bar{n} \\
\overline{\underline{n}}\end{array}$ & 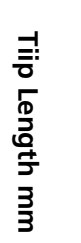 \\
\hline E. enysii & $\pm 50^{\circ}$ & - & $\mathrm{s}$ & - & - & - & $g$ & - & + & $\wedge$ & $\mathrm{b}$ & 0.00 \\
\hline E.scaber v plurinervis & $<30^{\circ}$ & obl & s & $\mathrm{b}$ & - & $f$ & $\mathrm{~g} / \mathrm{gs}$ & - & । & $\cap$ & $\mathrm{e} / \mathrm{r}$ & 0.37 \\
\hline E. scaber $v$ scaber & $<30^{\circ}$ & $\mathrm{ov} / \mathrm{c} / \mathrm{ob}$ & । & $\mathrm{t}$ & + & $s / f$ & $s / m$ & s & - & $\curvearrowright / \wedge$ & $\mathrm{e} / \mathrm{r} / \mathrm{b}$ & 0.07 \\
\hline E. rectisetus A & $<30^{\circ}$ & el & lc & $n$ & - & $r$ & $\mathrm{~m}$ & s & - & $\curvearrowright / \wedge$ & $\mathrm{e} / \mathrm{r} / \mathrm{b}$ & 0.45 \\
\hline E. rectisetus $\mathrm{N}$ & $<30^{\circ}$ & $o b$ & । & $n / t$ & + & $f$ & $\mathrm{~s} / \mathrm{m}$ & s & - & $\cap$ & $\mathrm{e} / \mathrm{r}$ & 0.08 \\
\hline E. multiflorus A & $<30^{\circ}$ & $\mathrm{ob} / \mathrm{c}$ & s & $b$ & - & $s / f$ & $\mathrm{~g} / \mathrm{gs}$ & I & - & $\cap$ & $\mathrm{e} / \mathrm{r}$ & 0.09 \\
\hline E. multiflorus $\mathrm{N}$ & $<30^{\circ}$ & $o b$ & s & $b$ & - & s & $\mathrm{g} / \mathrm{gs}$ & I & - & $\cap$ & e & 0.00 \\
\hline E. apricus & $<30^{\circ}$ & $o b$ & I & $t / b$ & $-/+$ & $s / f$ & $\mathrm{~s} / \mathrm{m}$ & s & - & $\wedge / \cap$ & $\mathrm{b} / \mathrm{r}$ & 0.07 \\
\hline E. falcis & $<30^{\circ}$ & $o b$ & $s / l$ & $\mathrm{t}$ & $-/+$ & $\mathrm{s}$ & $\mathrm{g} / \mathrm{s} / \mathrm{m}$ & s & - & $\wedge / \cap$ & $b / r$ & 0.00 \\
\hline E. sacandros & $<30^{\circ}$ & ob/ov & I & $t$ & - & $s / f$ & $\mathrm{~s} / \mathrm{m}$ & s & - & $\wedge$ & $\mathrm{b} / \mathrm{e}$ & 0.00 \\
\hline E. solandri & $<30^{\circ}$ & $\mathrm{ob} / \mathrm{c} / \mathrm{ov}$ & $s / 1$ & $b$ & - & $r$ & $\mathrm{~m} / \mathrm{s}$ & $s$ & - & $\wedge / \cap$ & $b / r$ & 0.12 \\
\hline E. tenuis & $<30^{\circ}$ & $o b / c$ & $s / 1$ & $n / t$ & $-/+$ & s & $\mathrm{gs} / \mathrm{s}$ & s & - & $\wedge$ & $b$ & 0.02 \\
\hline
\end{tabular}

A clear distinction could be drawn between the rachillas of Australian and New Zealand material of E. rectisetus (Fig. 1). Australian individuals of this species possessed trichomes densely distributed on the upper and central portion of rachillas. As a consequence the trichomes covered the base of calluses (Fig. 1a). Individuals of E. rectisetus from New Zealand had a more or less even covering of trichomes across the entire surface of the rachilla but, in contrast with Australian material, the trichomes did not cover the base of the calluses. In this respect, New Zealand material was more similar to Australian individuals of E. scaber var. scaber (Fig. 1b). In addition, one sample of E. sacandros (Druce s.n., CHR387017) could be distinguished from others by its extremely dense and very long-hairy rachillas (Fig. 1f).

The point at which the callus is inserted on to the rachilla was regularly facing inwards (an angle of $<30^{\circ}$ was formed between the side margins and the axis of rachilla; Fig. $1 \mathrm{a}-\mathrm{d}, \mathrm{f}$ ) with the exception of $E$. enysii which had a nearly horizontal (angled at $\pm 50^{\circ}$ ) and sharply expanded rachilla apex (Fig. 1e). This character unambiguously distinguishes E. enysii from all other Australian and New Zealand species. 
The shape of rachilla apices (with the exception of E. enysii) was also variable. Semicircular to oblate rachilla apices occur in E. scaber var. plurinervis (Fig. 1c), elliptical rachilla apices characterise Australian E. rectisetus (Fig. 1a), whereas, circular, ovate and obovate rachilla apices were observed in the remainder (Fig. 1b, d, f).

\section{Calluses}

The variation of the abaxial view of calluses involves the shape, the distribution of the indumentum and whether the tip is thickened or not. The calluses of Elymus enysii

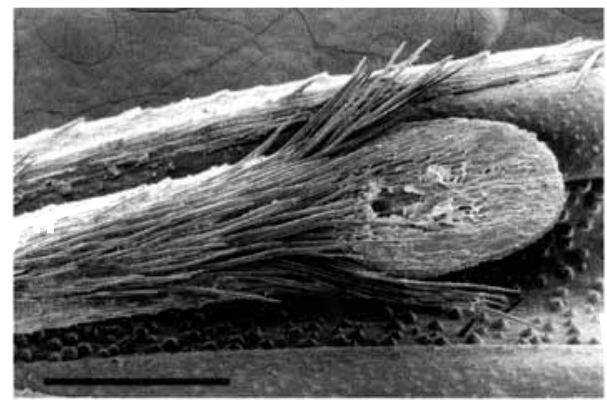

a

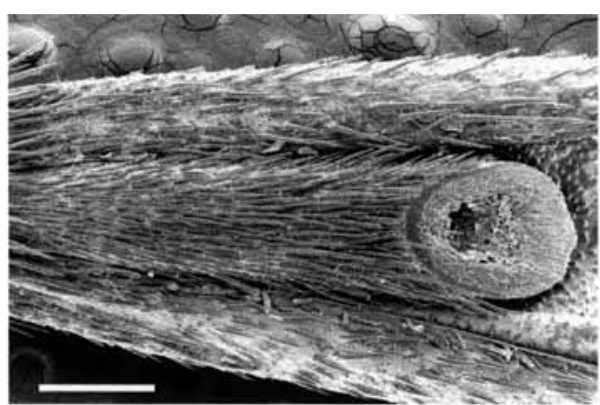

b

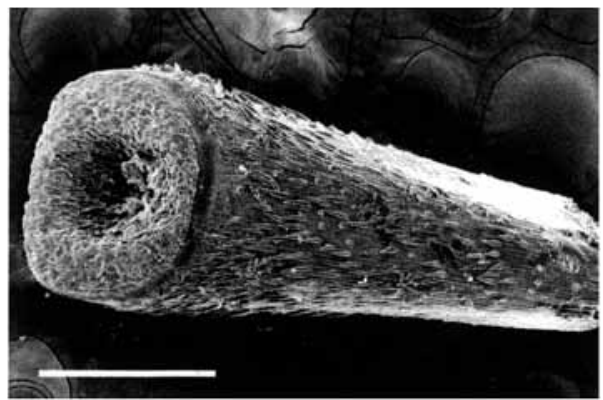

C

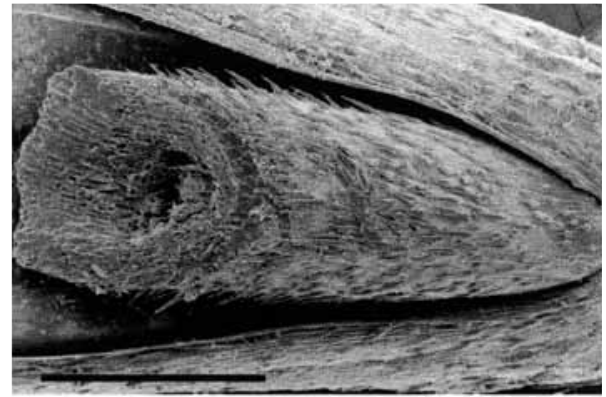

d

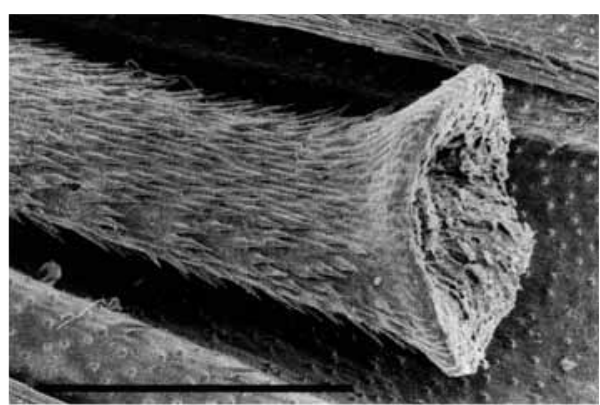

e

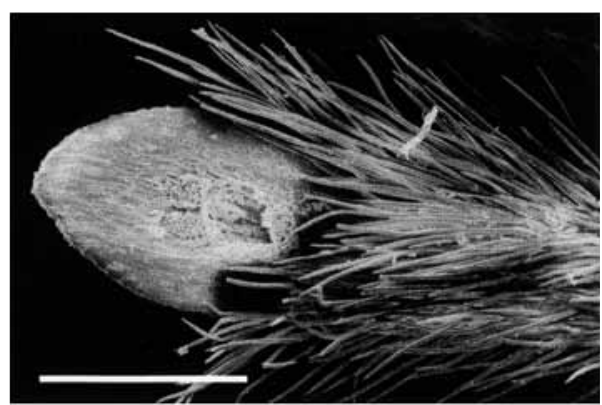

Fig. 1. Scanning electron micrographs of rachillas (calluses removed). a, E. rectisetus. Rachilla hairs long and dense, covering callus base; rachilla apex elliptical (Wang 95087). b, E. scaber var. scaber. Rachilla hairs long but not covering callus base; rachilla apex obovate (Wang 95135). c, E. scaber var. plurinervis. Rachilla hairs short; rachilla apex oblate (Smith \& Everist 811A). d, E. multiflorus. Rachilla hairs short; rachilla apex obovate (CHR 1594). e, E. enysii. Rachilla hairs short; rachilla apex \pm horizontal, sharply expanded (Druce 1345). f, E. sacandros. Rachilla hairs very long and dense, rachilla apex ovate (CHR 387017). Scale bars $=0.5 \mathrm{~mm}$. 
were very short and glabrescent (Fig. 2e) and distinct from all other species. Australian E. rectisetus was characterised by narrowly triangular and dorsally rounded calluses with hairs restricted to the margins (Fig. 2a). Elymus apricus, E. sacandros, E. falcis, E. scaber var. scaber and New Zealand material of E. rectisetus had mostly triangular, hairy calluses, the trichomes on which were located on the surface and the margins (as in Fig. 2b). In E. scaber var. scaber, the callus tips were thickened (Fig. 2b) as were the callus tips of New Zealand material of E. rectisetus, but not Australian material of this species. Thickened callus tips were also occasionally observed in E. apricus, E. falcis and E. tenuis (Table 2). Elymus scaber var. plurinervis differed from all other species by its uniformly broadly triangular and glabrous to glabrescent calluses with markedly blunt tips (Fig. 2c). Elymus multiflorus was characterised by broadly triangular calluses, but the tips was not as blunt as those of E. scaber var. plurinervis (Fig. 2d). One sample of E. sacandros (Druce s.n., CHR387017) had triangular calluses with very dense and long hairs on the surface (Fig. 2f), whereas the calluses of other samples were triangular and hairy, similar to those of E. scaber var. scaber.

The adaxial surface of the calluses was generally not as taxonomically informative as the abaxial surface. However, some variation was observed. The callus margins of all species (except E. enysii) were thickened. The extent of thickening varied between species and either extended approximately to the mid-point of the callus (Fig. 3b, c) or was restricted to below the mid-point (Fig. 3a, e, f). Attenuated callus thickening correlated with narrowly triangular to triangular, adaxially hairy calluses, whereas species with extended callus thickening possessed broadly triangular, glabrescent calluses.

In all taxa except $E$. enysii, the adaxial surfaces of calluses were sunken or somewhat flat (Fig. 3a-c, e, f). Elymus enysii could easily be distinguished from all other species on account of its raised adaxial callus surfaces (Fig. 3d).

\section{Paleae}

Australian taxa were mostly characterised by paleae with truncate or obtuse, and entire or retuse apices (Fig. $4 \mathrm{a}-\mathrm{d}$ ). In contrast, New Zealand taxa, except E. multiflorus and E. rectisetus, were mostly characterised by pointed and bifid palea apices (Fig. 4e, f). The attenuated palea flanks of Australian individuals of E. rectisetus (Fig. 4b) set them apart from the New Zealand members of this species.

\section{Discussion}

Elymus species from Australia and New Zealand form three broad groups based on their rachilla and callus characters. Two of the groups each consist of only one taxon, with the remaining taxa comprising the third group. The third group can be further subdivided into two groups by employing palea characters.

Elymus enysii constitutes a single-member group. This species is characterised by sharply expanded rachilla apices, very short (abaxial) and distinctly raised (adaxial) calluses. The unique combination of micromorphological characters described here corresponds with the notion proposed by Svitashev et al. (1996) and Svitashev et al. (1998) that E. enysii may be misplaced within Elymus. Their study confirmed the presence of the $\mathrm{H}$ and $\mathrm{W}$ genomes, but they were unable to locate the $S$ genome in E. enysii. The $S$ genome is widely considered to be common to all Elymus species (Svitashev et al. 1996). That the micromorphological characters seem to be sensitive to genomic constitution has been previously suggested by Salomon and Lu (1992). Thus, the combined genomic and micromorphological evidence would suggest that a revision of the generic status of E. enysii is appropriate. 


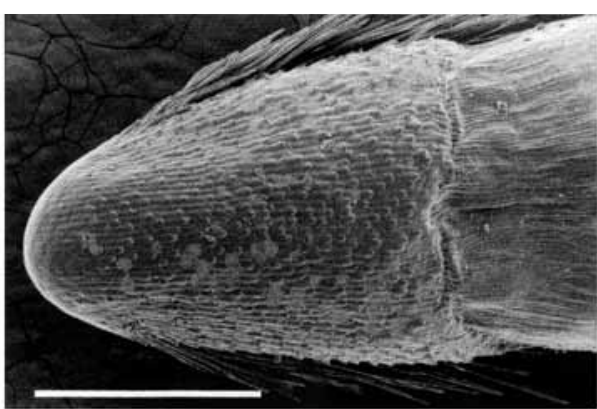

a

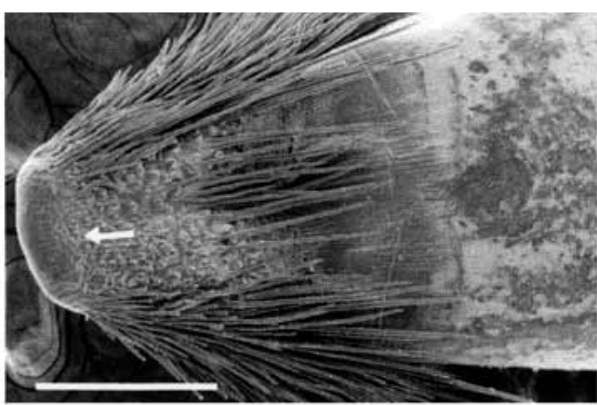

b

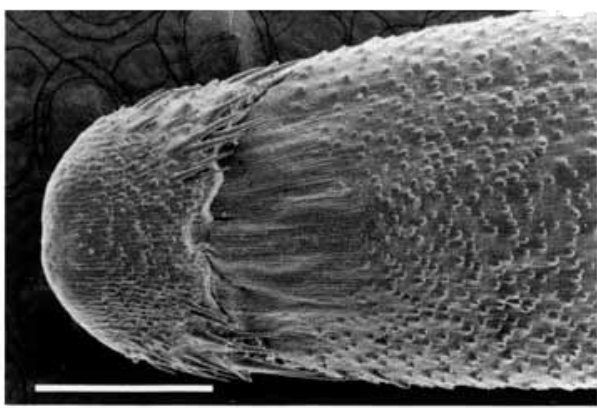

C
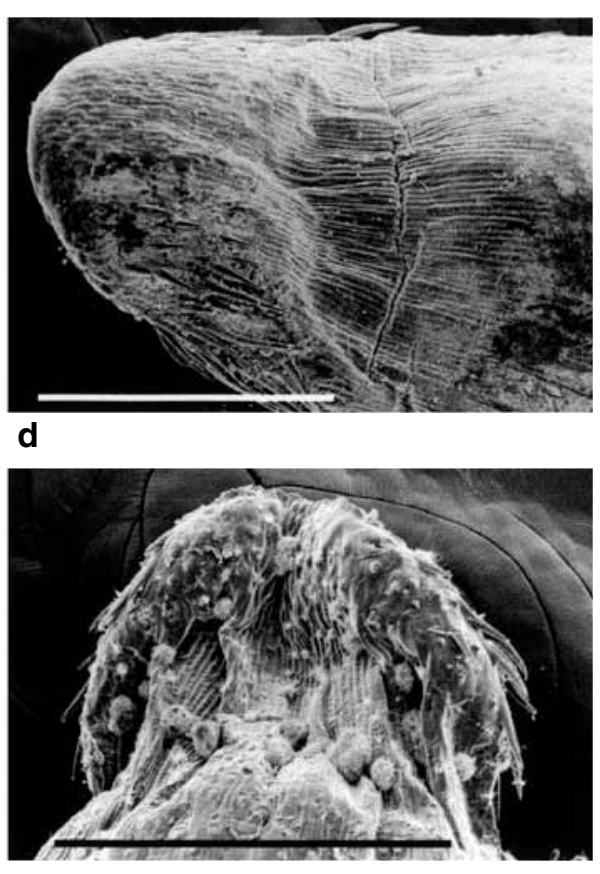

e

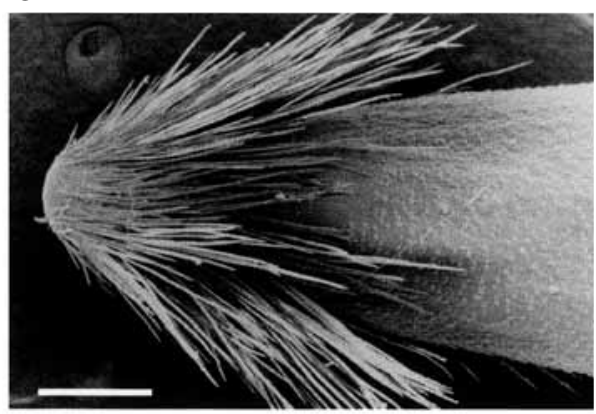

f

Fig. 2. Scanning electron micrographs of calluses (abaxial surface). a, E. rectisetus. Callus narrowly triangular; dorsal surface rounded; hairs restricted to margins; tip not thickened (Wang 95001). b, E. scaber var. scaber. Callus triangular; dorsal surface sunken; hairs on margins and surface; tip thickened (arrow) (Willis s.n.). c, E. scaber var. plurinervis. Callus broadly triangular; dorsal surface flat, glabrescent; tip not thickened and markedly blunt (Fensham 1728). d, E. multiflorus. Callus broadly triangular; dorsal surface flat, glabrescent (CHR 1594). e, E. enysii. Callus latitudinally much wider than longer and glabrescent (Lempson 3442). f, E. sacandros. Callus triangular, dorsal surface flat; hairs long and dense, distributed on margins and surface; tip not thickened (CHR 387017). Scale bars $=0.5 \mathrm{~mm}$. 


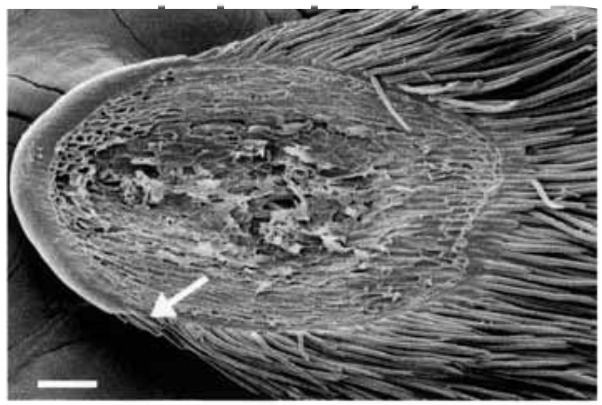

a

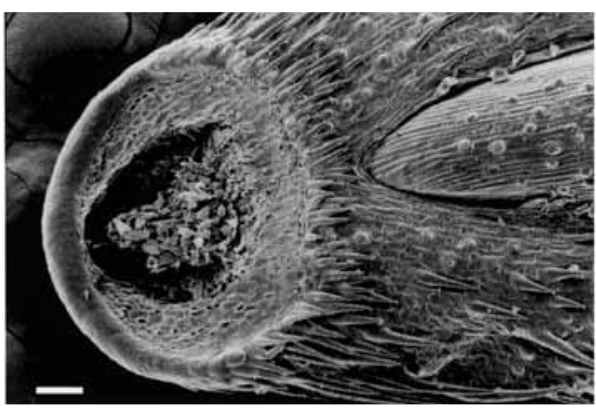

b

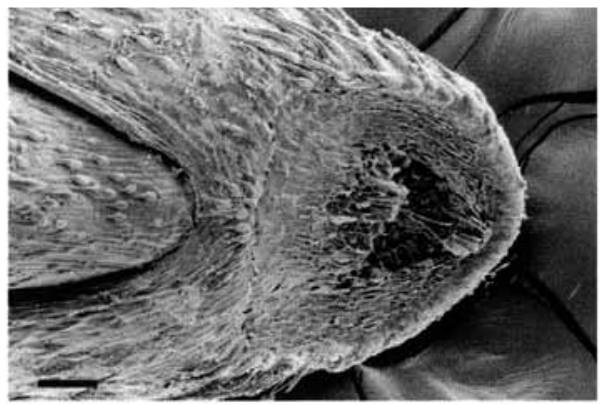

C

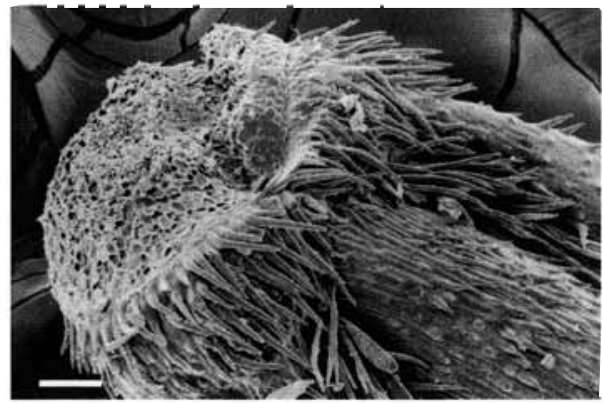

d

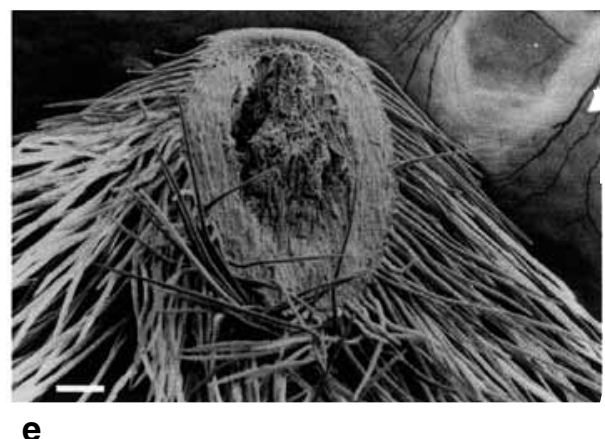

e

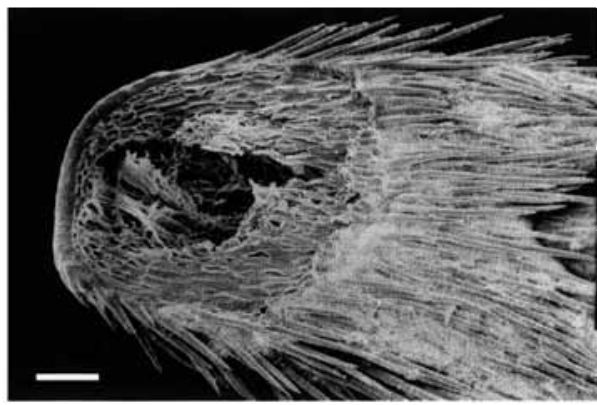

f

Fig. 3. Scanning electron micrographs of calluses (adaxial surface). a, E. rectisetus. Callus flat; marginal thickening distinct (arrow), restricted to below the mid-point; hairy (Wang 95001). b, E. scaber var. plurinervis. Callus sunken; marginal thickening distinct, extending approximately to the mid-point; glabrescent (Fensham 1343). c, E. multiflorus. Callus sunken; marginal thickening distinct, extending approximately to the mid-point; glabrous (CHR 1594). d, E. enysii. Callus raised, with remnants of rachilla; marginal thickening not distinct; hairy (Druce 1345). e, E. sacandros. Callus sunken; marginal thickening distinct, restricted to below the mid-point; hairy (CHR 387017). f, E. apricus. Callus sunken, marginal thickening distinct, restricted to below the midpoint; hairy (Johnson 1220). Scale bars $=0.1 \mathrm{~mm}$. 
The Australian taxon, E. scaber var. plurinervis, also forms a single-member group. Elymus scaber var. plurinervis is separable from all other taxa by its uniformly semicircular to oblate rachilla apices and widely triangular and glabrous calluses with markedly blunt tips. This result agrees with the suggestion of several authors (Carman \& Wang 1992; Connor, pers. comm.) that this taxon should be elevated to species rank.

The remaining taxa comprise the third group on account of their more variable characters of rachilla apices (elliptical, ovate, obovate and circular), callus shape (abaxial; from narrowly triangular to broadly triangular) and indumentum (glabrous

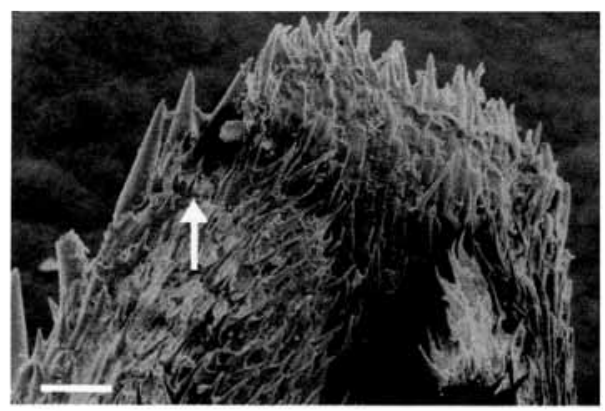

a

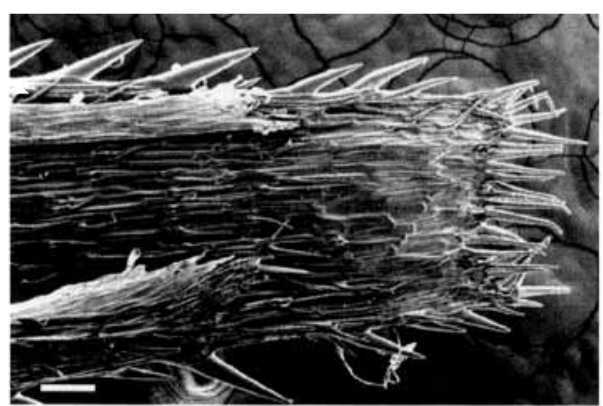

b

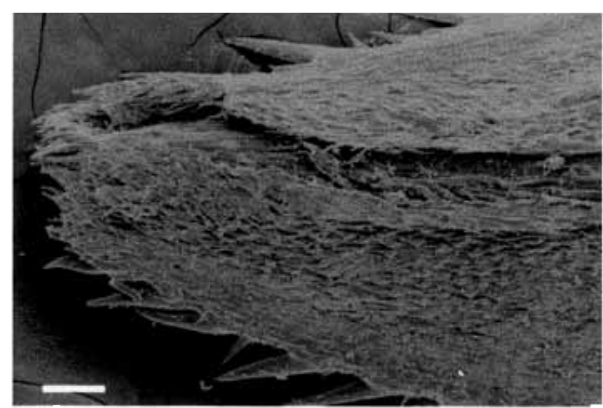

C
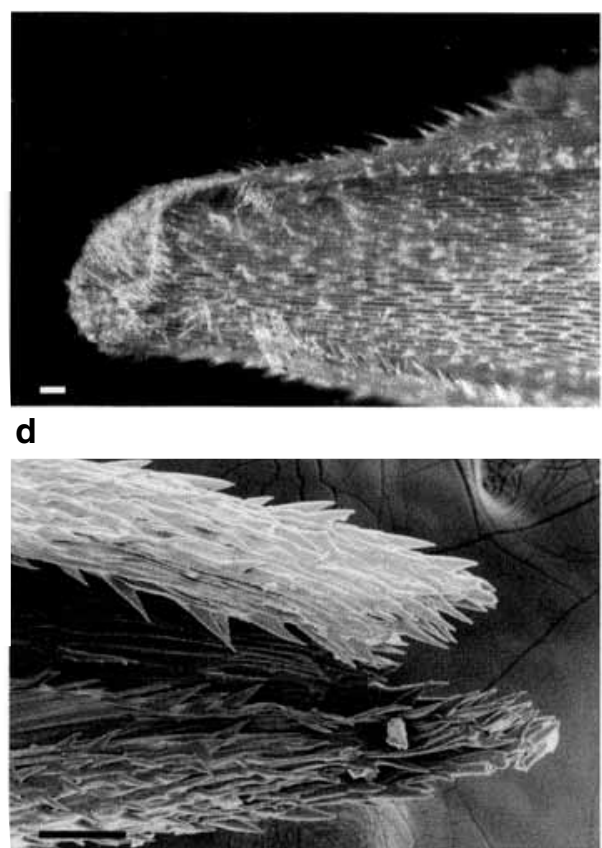

e

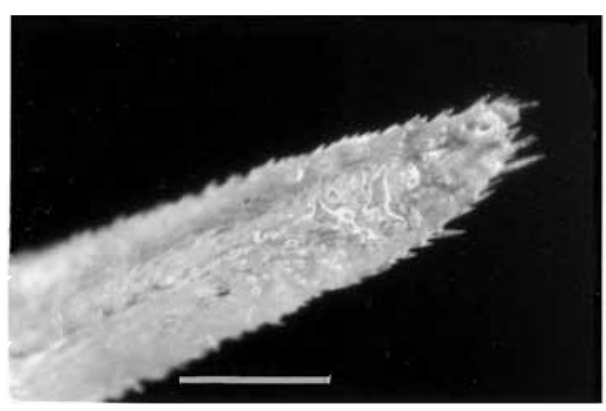

$\mathbf{f}$

Fig. 4. Palea apices and flanks (abaxial surface). a, E. scaber var. scaber. Apex truncate and entire; flanks ending under the top (arrow) (Wang 95129). b, E. rectisetus. Apex truncate and entire; flanks ending far away under the top (Wang 95041). c, E. multiflorus. Apex truncate and entire; flanks ending at the top (CHR 1594). d, E. scaber var. plurinervis. Palea apex obtuse and retroflex; flanks ending under the top (Smith $\mathcal{E}$ Everist 811 A). e, E. tenuis. Apex pointed and bifid; flanks ending at the top (CHR 402401). f, E. enysii. Palea apex acute and bifid; flanks ending at the top (Druce 1345). Scale bars: a-e $=0.1 \mathrm{~mm} ; \mathrm{f}=0.5 \mathrm{~mm}$. 
to hairy; Table 2). The subdivision of this group is based on the characters of palea apices. The first sub-group is made up by E. scaber var. scaber, E. rectisetus (both Australian and New Zealand material) and E. multiflorus, and is characterised by truncate or obtuse and entire to retuse palea apices. The remaining species, E. apricus, E. falcis, E. sacandros, E. solandri and E. tenuis, regularly have pointed and bifid palea apices.

Fine details of the surveyed organs do, however, permit further resolution of the taxa. For example, Australian individuals of E. rectisetus are readily distinguishable from E. scaber var. scaber when micromorphological characters are used. These taxa are customarily considered to be conspecific in Australia on account of their long awns (Crane \& Carman 1987; Ross 1989; Jacobs \& Hastings 1993; Walsh 1994; Murphy \& Jones 1999). Australian members of E. rectisetus are characterised by elliptical rachilla apices, long rachilla trichomes covering callus bases, narrowly triangular calluses with hairs restricted to the margins, and attenuated palea flanks (Table 2). Elymus scaber var. scaber, on the other hand, has ovate to obovate rachilla apices, long rachilla trichomes (but not covering callus bases), triangular calluses with hairs distributed on the margins and surfaces, thickened callus tips and elongated palea flanks (Table 2). In contrast, New Zealand E. rectisetus is indistinguishable from Australian E. scaber var. scaber, thereby raising the possibility that they may be conspecific. This conclusion is in direct conflict with Löve and Connor (1982) who concluded that E. scaber var. scaber does not occur in New Zealand.

In general, the micromorphological characters obtained from rachillas, calluses and palea apices were found to be taxonomically informative. To a limited extent the micromorphological characters are congruent with the characters traditionally used in defining the species of Elymus. For example, rachillas and calluses with long hairs correlate with lemmas characterised by intermediate to long awns (with the exception of E. scaber var. plurinervis), and semi-circular or oblate rachilla apices correlate with large glumes. Individuals with short awns (except E. scaber var. plurinervis) have rachillas with short hairs and broadly triangular, glabrous to glabrescent calluses.

The above mentioned micromorphological characters also appear to correlate with the modes of reproduction encountered in E. scaber s.l. Elymus scaber var. scaber and E. rectisetus (including Australian individuals) are putatively apomictic (Crane \& Carman 1987; Torabinejad et al. 1987; Murphy \& Jones 1999), and each possesses long-hairy calluses and rachillas. In contrast, the sexual taxa E. multiflorus and E. scaber var. plurinervis are characterised by broadly triangular and glabrous calluses, and by rachillas with short trichomes.

The micromorphological characters indicate that the taxonomic limits of some species may require adjustment. Elymus enysii may be misplaced within Elymus. Furthermore, it would appear that the Australian and New Zealand members of E. rectisetus differ micromorphologically from each other, thereby, raising the possibility that individuals from each country are not conspecific. Australian material of E. rectisetus agrees well with the holotype of this species, whereas material determined as E. rectisetus from New Zealand shows a closer micromorphological affinity with E. scaber than with typical E. rectisetus.

From a practical point of view, the characters outlined in this paper provide a further means of defining the taxa of Elymus from New Zealand and Australia. In addition, we believe that these characters are less ambiguous and, therefore, can be applied more rigorously than the characters employed traditionally in this genus. 


\section{Acknowledgments}

We thank the heads of the following herbaria: AD, BM, BRI, CHR, HO, K, MEL, NSW, PERTH for granting access to their collections and Tony Romeo for SEM preparation and technical advice.

\section{References}

Carman, J.G. \& Wang, R. R.-C. (1992) Apomixis in the Triticeae. Pp. 26-29 in Elgin, J.H. \& Miksche, J.P. (eds) Proceedings of the Apomixis Workshop. (USDA-ARS: Atlanta).

Connor, H.E. (1954) Studies in New Zealand Agropyron. New Zealand J. Sci. Technol. 35B: 315-343.

Connor, H.E. (1956) Interspecific hybrids in New Zealand Agropyron. Evolution 10: 415-420.

Connor, H.E. (1962a) Studies in New Zealand Agropyron Part 3. Intraspecific hybrids in A. scabrum (R. Br. ) Beauv. New Zealand J. Sci. 5: 99-115.

Connor, H.E. (1962b) Studies in New Zealand Agropyron Part 4. Interspecific hybrids A. scabrum (R. Br.) Beauv. X A. kirkii Zotov. New Zealand J. Sci. 5: 116-119.

Connor, H.E. (1994) Indigenous New Zealand Triticeae: Gramineae. New Zealand J. Bot. 32: 125-154.

Crane, C.F. \& Carman, J.G. (1987) Mechanisms of apomixis in Elymus rectisetus from eastern Australia and New Zealand. Amer. J. Bot. 74: 477-496.

Hair, J.B. (1956) Subsexual reproduction in Agropyron. Heredity 10: 129-160.

Holmgren, P.K., Holmgren, N.H. \& Bartlett, L.C. (1990) Index Herbariorum, ed. 8. (New York Botanical Garden: New York).

Jacobs, S.W.L. \& Hastings, S.M. (1993) Elymus. p. 601 in Harden, G.J. (ed.), Flora of New South Wales, vol. 4. (New South Wales University Press: Sydney).

Jessop, J.P. (1986) Elymus L. Pp. 1882-1884 in Jessop, J.P. and Toelken, H.R., (eds.) Flora of South Australia, vol. 4. (South Australian Government Printing Division: Adelaide).

Löve, A. \& Connor, H.E. (1982) Relationships and taxonomy of New Zealand wheatgrasses. New Zealand J. Bot. 20: 169-186.

Lu, B.R. (1995) Taxonomy and morphology of the Elymus parviglumis group (Triticeae). Nordic J. Bot. 15: 3-37.

Murphy, M.A. \& Jones, C.E. (1999) Observations on the genus Elymus (Poaceae: Triticeae) in Australia. Austral. Syst. Bot. 12: 593-604.

Ross, E.M. (1989) Elymus. Pp. 135-136 in Stanley, T.D. \& Ross, E.M. (eds), Flora of South-eastern Queensland, vol. 3. (Queensland Department of Primary Industries: Brisbane).

Salomon, B. \& Lu, B.R. (1992) Genomic groups, morphology, and sectional delimitation in Eurasian Elymus (Poaceae, Triticeae). Pl. Syst. Evol. 180: 1-13.

Simon, B.K. (1980) A Key to Queensland Grasses. (Queensland Department of Primary Industries: Brisbane).

Simon, B.K. (1993) A Key to Australian Grasses. (Queensland Department of Primary Industries: Brisbane).

Svitashev, S., Bryngelsson, T., Li, X.-M. \& Wang, R.R.-C. (1998) Genome-specific repetitive DNA and RAPD markers for genome identification in Elymus and Hordelymus. Genome 41: 120-128.

Svitashev, S., Salomon, B., Bryngelsson, T. \& Von Bothmer, R. (1996) A study of 28 Elymus species using repetitive DNA sequences. Genome 39: 1093-1101.

Torabinejad, J., Carman, J.G. \& Crane, C.F. (1987) Morphology and genome analyses of interspecific hybrids of Elymus scaber. Genome 29: 150-155.

Vickery, J.W. (1951) Contributions to the Taxonomy of Australian Grasses. Contr. New South Wales Natl. Herb. 1: 342-343.

Walsh, N.G. (1994) Poaceae. Pp. 356-625 in Walsh, N.G. and Entwisle, T.J. (eds), Flora of Victoria, vol. 2. (Inkata Press: Melbourne).

Wheeler, D.J.B., Jacobs, S.W.L. \& Norton, B.E. (1982) Grasses of New South Wales. (University of New England Publishing Unit: Armidale). 